Article received on August 27 2017

Article accepted on November $13^{\text {th }} 2017$

UDC: 78.036 .7

75.036 .7

\author{
Anastasia Siopsi* \\ Ionian University, Corfu \\ Music Department, \\ School of Music and Audiovisual Arts
}

\title{
AURAL AND VISUAL MANIFESTATIONS OF THE SCREAM IN ART, BEGINNING WITH EDVARD MUNCH'S DER SCHREI DER NATUR ${ }^{1}$
}

\begin{abstract}
In Munch's painting entitled Der Schrei der Natur (1893), a figure, while walking on a bridge, feels the cry of nature, a sound that is sensed internally rather than heard with the ears. The Scream is thought to be the ultimate embodiment of fear, angst and alienation. It is also thought to symbolize humanity's existential panic expressed by ugly, even hideous, sounds of living beings undergoing both physical and emotional suffering in the modern age.
\end{abstract}

\footnotetext{
* Author contact information: siopsi@ionio.gr

1 This article was initially written in Greek, under the same title, as a paper to be presented at the $3^{\text {rd }}$ conference of the Greek Musicological Society, 25-27 November 2016, Athens. The annuals will be published as an e-book on the website of the Greek Musicological Society (http://musicology.mus.auth.gr/) .
} 
As a motive, the so-called Ur-schrei is manifested mainly, but not only, in expressionist literature, painting and music, in order to articulate the most intense human emotions. In this article, I will present and analyze aural and visual manifestations of the Scream in music and painting.

Key words: scream, primal scream (Ur-schrei), expressionism, atonal music, idea of man's alienation from nature.

Toward the end of the nineteenth century, at the same time that the well-known psychiatrist Siegmund Freud (1856-1939) was exploring unconscious phenomena and the influence of childhood events on the causation of neurosis, a Norwegian artist who was barely known, Edvard Munch (1863-1944), began to express his tormented inner world through his artistic creations, giving birth to an art style that would later be known as Expressionism.

The Scream is the most well-known work of the Norwegian painter, depicting a screaming figure on a bridge who feels the cry of nature, a sound that is sensed internally rather than heard with the ears. An entry in Munch's diary, dated 22 January 1892, recorded the inspiration for this painting as follows:

I was walking down the road with two friends when the sun set; suddenly, the sky turned as red as blood. I stopped and leaned against the fence, feeling unspeakably tired. Tongues of fire and blood stretched over the bluish black fjord. My friends went on walking, while I lagged behind, shivering with fear. Then I heard the enormous infinite scream of nature.

The Scream was conceived as part of Munch's semi-autobiographical cycle, a series of paintings that he called The Frieze of Life, which together present a picture of life. ${ }^{2}$

The Scream's composition exists in four forms that were painted in 18891909 (Example 1). The first painting, done in oil, tempera, and pastel on cardboard (1893, National Gallery of Art, Oslo); two pastel examples (1893, Munch Museum, Oslo and 1895, private collection); and a final tempera painting (1910, National Gallery of Art, Oslo). Munch also created a lithographic version in 1895. (Example 2)

\footnotetext{
${ }^{2}$ The Frieze of Life was conceived by Munch as a series of paintings presenting a picture of life. The years between 1889 and 1909 are the years in which the main corps of the pictures were painted. However, the artist worked on the Frieze at long intervals for over thirty years. As the artist himself writes, in a commentary in 1918, "the Frieze is a poem of life, love and death". Paintings that are included are: The Kiss, Yellow Boat, The Riddle, Man and Woman, Fear, Vampire, The Scream, Madonna. (See J.P. Hodin, Edvard Munch, London, Thames and Hudson, 1972, 55-56)
} 
Siopsi, A., Aural and Visual Manifestations of the Scream in Art...
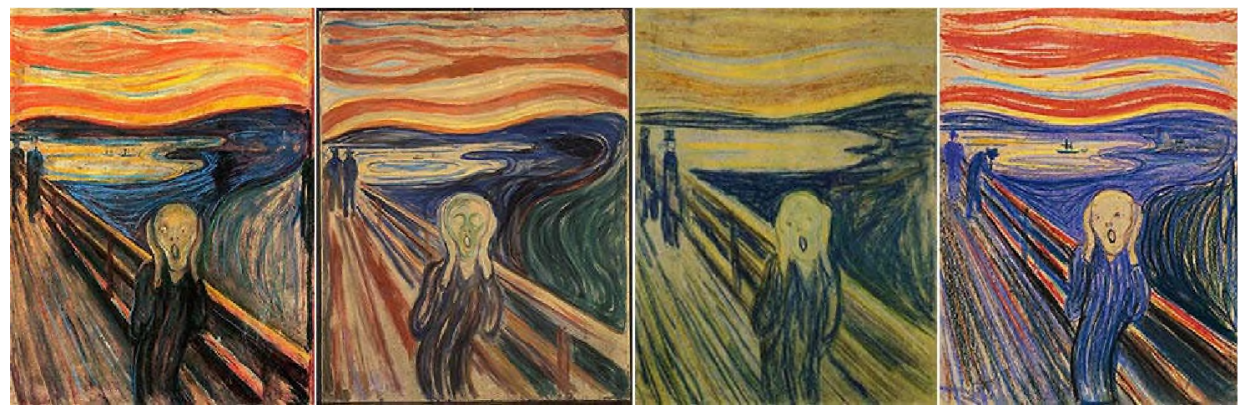

Example 1: Der Schrei der Natur, 1893-1910. Part of The Frieze of Life. The four versions of the Scream.

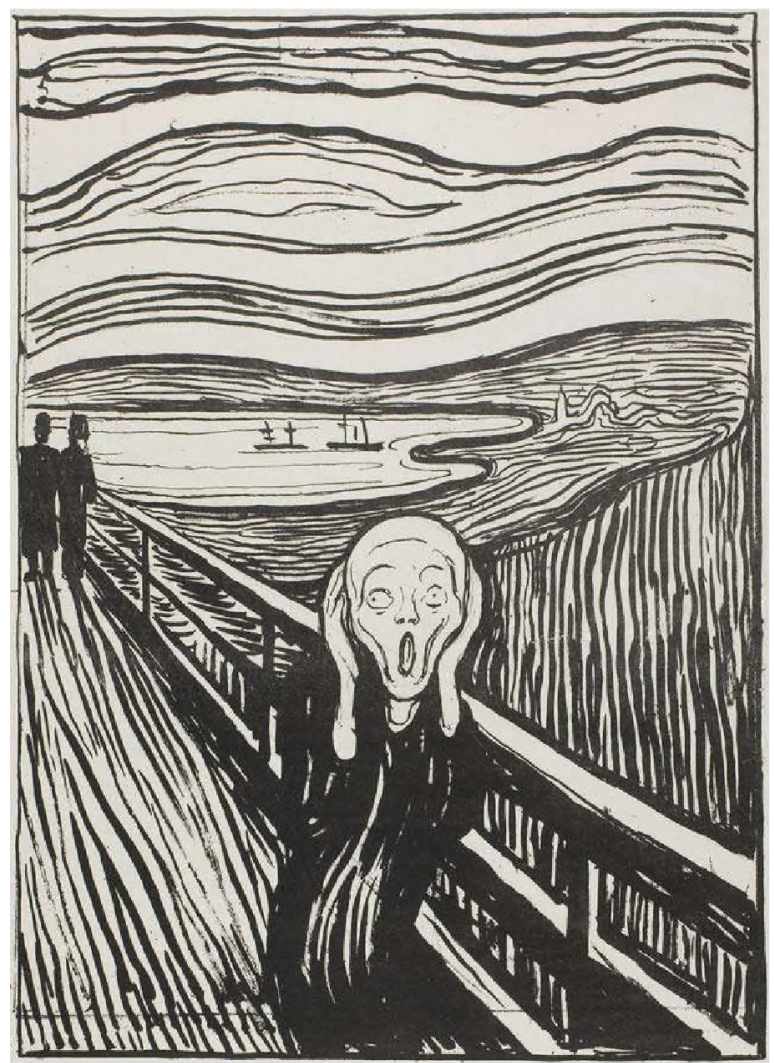

Example 2: Woodcut, 1895. This version of the Scream was more widely known at the beginning of the twentieth century. 
They articulate repeatedly the same idea: that of the profound dissonance with one's sonic environment - the idea is also indicated by the title given by the artist himself, Der Schrei der Natur.

Munch's friend and important playwright and novelist August Strindberg $(1849-1912),{ }^{3}$ characteristically describes the painting in a prose-poem written on some of Munch's pictures for the Revue Blanche, as follows:

The Scream: A scream of dread at Nature, which, flushed with rage, is about to speak through storm and thunder to those foolish, puny beings who imagine themselves to be gods without resembling gods. ${ }^{4}$

Thus, the painting depicts a torturing scream which is transferred through visible pulses in the air, like sonar waves. Long, waving lines seem to embrace the echo of this scream and diffuse it at every part of the work: a sense of primal, overwhelming horror. The artist's interior world penetrates the image or, according to Munch, panic attacks which are well hidden from visual reality. Nevertheless, in this painting Munch's approach to the experience of synesthesia, or the union of the senses, becomes apparent and this results in the visual depiction of sound and emotion. More specifically, the artist's aim was to express the ways that a sudden emotion can change all the impressions of the senses.

As such, the Scream represents a key work for the Symbolist movement as well as an important inspiration for the Expressionist movement of the early twentieth century from which I derive the musical examples that I present in the present article as well as the first visual example. This painting represents, by all means, the essence of Expressionism, a movement which includes extreme and unconventional works of art, with the predominant characteristics of intense emotion and a persistent sense of duty to express this kind of truth which derives from a primitive state and/or the depth of soul (subconsciousness).

It goes without saying that its symbolism goes beyond the limits of expressionism since it embraces the existential fear (angst) of contemporary man in

\footnotetext{
${ }^{3}$ Strindberg and Edvard Munch were inseparable friends during the time Munch was planning and painting the Scream. Strindberg's then-revolutionary idea that Chance should be allowed to play a role in artistic creation loosened up Munch's work to embrace random happenings. You can see a bird dropping on the Scream torso and the splatter-pattern of candlewax in the right-hand bottom corner that suggests Munch painted the picture at night, blew out the candle carelessly and never bothered to try to remove the wax. In Strindberg's words, "these physical traces bind chance with creation in a metamorphosis surpassing Ovid" in creating a dynamic interaction between the artwork and the real world ("Strindberg, A Life - Sue Prideaux in the Playwright's Relationships", http://yalebooksblog.co.uk/2013/07/08/ strindberg-a-life-author-sue-prideaux-on-the-playwrights-relationships/ [14\8\16])

${ }^{4}$ Quoted in J.P. Hodin, op. cit., 76.
} 
our frantic society. Also, together with Mona Liza, the Scream is one of the most frequently reproduced images in the world.

The focus in the present article is not so much on the painting itself as on the ideas it represents and the ways they are articulated in other works in music and visual arts which have as a central motive the primal scream (Ur-schrei), as the most extreme expression of emotional intensity. Munch's text itself refers to the 'enormous infinite scream of nature', directly corresponding to the feeling of doom in Vienna and Berlin in the 1890s, the end of an era, which is emblematically represented in an important study by $\mathrm{O}$. Spengler entitled Der Untergang des Abendlandes [The Decline of the West] (1918-1922), a study which moreover exerted great influence on many intellectuals all over Europe. Also, this painting was created in an era that Darwin and Nietzsche's works were causing a wider sense of anxiety. According to Sue Prideaux, the author of the award-winning biography of Munch, it is impossible to ignore this wider environment. It was Munch's ability to combine the deeply personal with the universal element that rendered it possible for his artwork to survive through time. ${ }^{5}$

The 'scream', seen from a philosophical point of view, contains such ideas as existential anguish, the ultimate fear and, mainly, alienation from nature. Munch's work, subsequently, is the absolute embodiment of fear, anguish and alienation. One can consider it as symbolizing humanity under the shuttering of existential horror.

\section{Main idea: man's alienation from nature}

The idea of 'nature's scream' is diachronic. It goes back to ancient Greek mythology, more specifically, to the myth of the rape of Persephone (see Example 3). ${ }^{6}$

Ana Mozol, a Jungian analyst in Vancouver, British Columbia, points to the myth of the rape of Persephone, whose abduction by the god of the underworld created winter. "This is the scream that went under and wasn't heard", she says. "And I think that that can also be amplified to the scream of nature or the scream of the earth."

\footnotetext{
5 Sue Prideaux, Edvard Munch. Behind the Scream, s.1., Yale University Press, 2005.

${ }^{6}$ Image in E.H. Gombrich, To Hroniko tis tehnis [The Art's Chronicle], Athens, Morfotiko Idrima Ethnikis Trapezis, 2003, 632.

7 Quoted in Margot Adler, "Scream Still Echoes After More Than A Century", in http://www. npr.org/2012/05/02/151706441/scream-still-echoes-after-more-than-a-century (21/8/2017).
} 


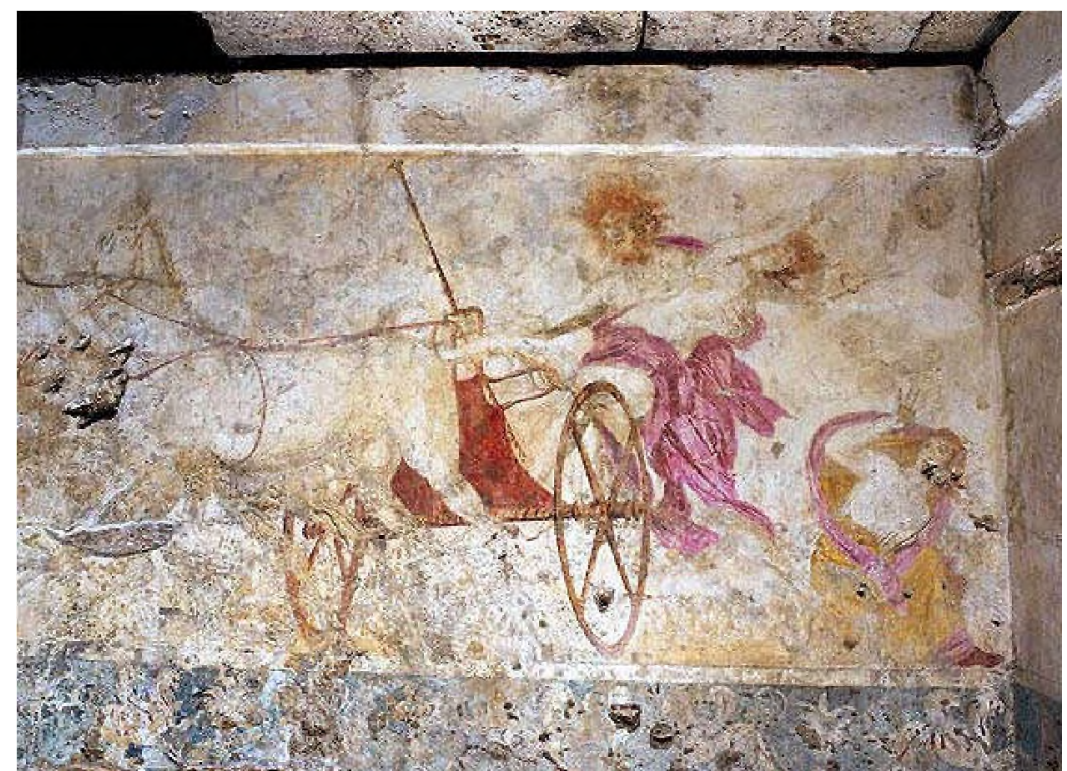

Example 3: The abduction of Persephone, c. 336 b.C., central part of a fresco in the royal tomb in Vergina, Northern Greece.

\section{Scream as a sound image}

The idea of man's alienation from nature is much older than Munch's work. It is at the core of romantic aesthetics. However, romanticism, in contrast to expressionism, believes in the solution of this problem, or else, envisions the reunion of man with nature. The most characteristic example is Richard Wagner's Tetralogy which has as a central idea the initial violent severance of man from nature (culture) and the final visionary suggestion of their reunion, at the end of the Tetralogy, which is signified purely by means of music. ${ }^{8}$

\footnotetext{
8 This idea is articulated in music as a passage from chromatic to diatonic harmony (I refer to the Tetralogy's end). The scream of the society, which is symbolically represented on stage as the community of the Gibichungs (the final scream when they become witnesses of the gesture of the dead hero Siegfried, raising his hand in order to prevent Hagen from stealing the ring), symbolizes the collective understanding of the severance of man from nature and signifies, by means of the following and last orchestral bars of the finale, the artist's vision which is the beginning of a new stage of humanity reconciled with nature. (See, in more detail, Anastasia A. Siopsi, "Mousiko stil os politiki ekfrasi sto metagenestero ergo tou me paradeigma tin Tetralogia [Music style as a political expression in his later work with Tetralogy as an example]", in Richard Wagner: Dokimia gia tin aisthitiki tis theorias kai tou ergou tou [Richard Wagner. Essays on the aesthetics of his theory and work], Athens, Papagrigoriou-Nakas publications (Greek Musicological Publications), 2013, 94-125).
} 
Expressionism has no such vision as romanticism, thus, similar to Munch's work, screams are left 'swinging', corresponding to unresolved dissonances in music and aiming at shocking and shaking the listener. The unresolved dissonance at the climax of a composition can correspond to fundamental human emotions in a rupture with the 'external' reality.

I begin with three examples of such screams, all from the atonal compositional period of Schoenberg which paradoxically, in my opinion, refer to Kundry, the main female protagonist in Wagner's last music drama, Parsifal (1882).

Pierrot Lunaire, 1912, op. 21, is Shoenberg's metaphor, in a representative way, of the early twentieth-century artist. This work, however, has a meaning beyond the above symbolism since it expresses 'inwardness' not only by means of ideas, that is, by suggesting Pierrot as expressing the inward sensitive 'Self' of a modern artist, but also through the work itself, in which music makes use of its internal material in order to state, by means of contrasting musical material and musical strategy, the crisis of musical language whose traditional forms were weakening.

In Pierrot we find a very characteristic reference in piece No. 9, Gebet an Pierrot, at the word Lachen (laugh), where the melodic line of the clarinet (Example 4) indirectly quotes the well-known scream of Kundry, from Wagner's Parsifal, at the word 'lachte', Act II (Example 5), functioning thus as a musical quotation. ${ }^{9}$ At this word Kundry sings from B3 two octaves lower to C\#. In Gebet an Pierrot, the clarinet seems to 'remember' what the protagonist, Columbina, seems to have forgotten or even has never known.

We can also trace symbolic similarities between Kundry and Pierrot having the idea of 'rupture', or, 'dichotomy' as a central one. Kundry is a woman divided in two parts and cursed to live at two different levels: on the one side, she unwillingly serves the Holy Grail in order to be redeemed for her sins, whereas, on the other side, she has to obey and serve the magician Klingsor. Terrified by his magic power, she has the duty of seducing the Knights of the Holy Grail. Dichotomy is also expressed through the symbolism of the image of Pierrot, since here it presents a modern artist in conflict with the world and also with himself. ${ }^{10}$

\footnotetext{
${ }^{9}$ There are more references to - especially Germanic - music tradition, to specific styles and works which are articulated with a certain clarity and give the impression of music quotations (see Anastasia Siopsi, "Esthitikes prosegiseis ston Pierrot Lunaire (1912), op. 21, tov Arnold Schoenberg [Aesthetic approaches to Pierrot Lunaire (1912), op. 21, by Arnold Schoenberg]", Porphyras (philological journal), Vol. KD', 107-110, n. 110, Jan.-Mar. 2004, 561-574).

${ }^{10} \mathrm{Also}$, from a musical point of view, at certain moments of Parsifal, the rhetoric character of the vocal parts (for example, in Amfortas "Die Wunde!") and the employment of disso-
} 


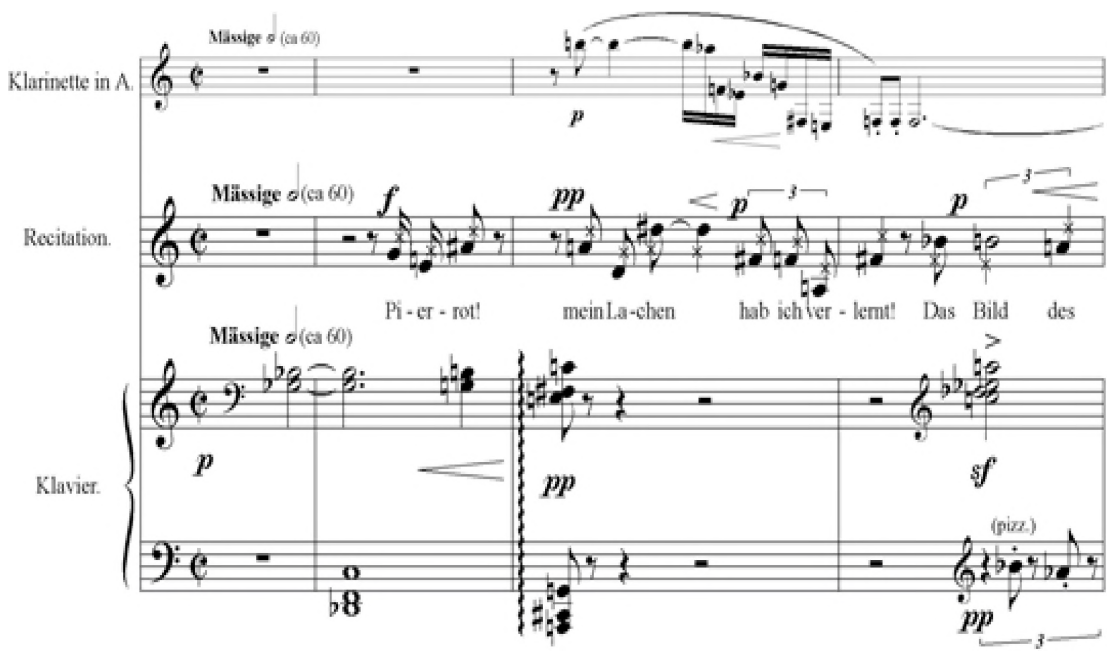

Example 4: No. 9, Gebet an Pierrot, text: "mein Lachen", clarinet's melodic line

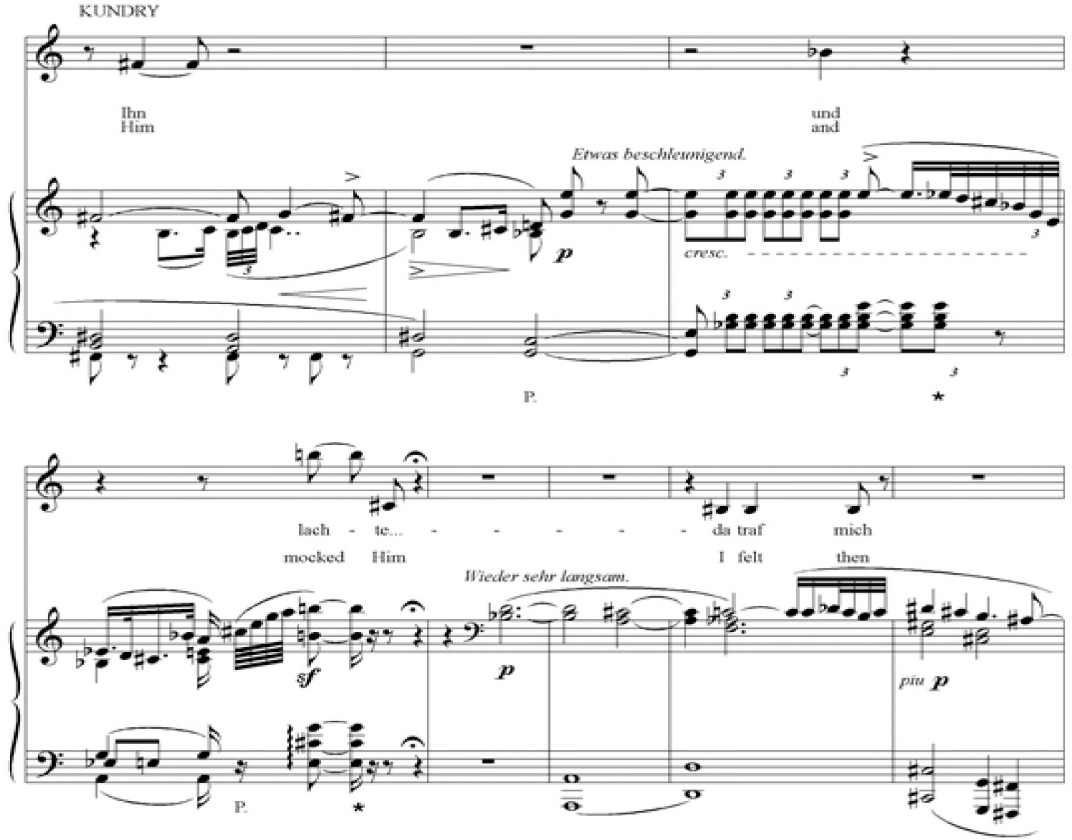

Example 5: Richard Wagner, Parsifal, Act II, b. 1182

nance are heard at the very limits of tonality, therefore, we can argue that they form the early stages of expressionism. In other words, we can consider this opera as the musical predecessor of Schoenberg's Pierrot Lunaire. 
Siopsi, A., Aural and Visual Manifestations of the Scream in Art...

The same musical quotation is realized in a more obvious way, and not by instruments but by means of a female voice, in two more works of Schoenberg, that is at the climax of Erwartung (1909), op. 17, bar 189, at the word "Hilfe" (help) of the Woman and at the climax of the Second String Quartet (1908), op. 10 , bars 63-68, works written in the same period that the composer wrote Pierrot Lunaire (1912) (Examples 6 and 7). A woman's scream for help stands at the apex of Erwartung. Shortly before the work's halfway mark as the vocalist sings her highest and longest note, with the largest change in register, Schoenberg's stage direction to her is "screaming; racing away from a lump on the ground".

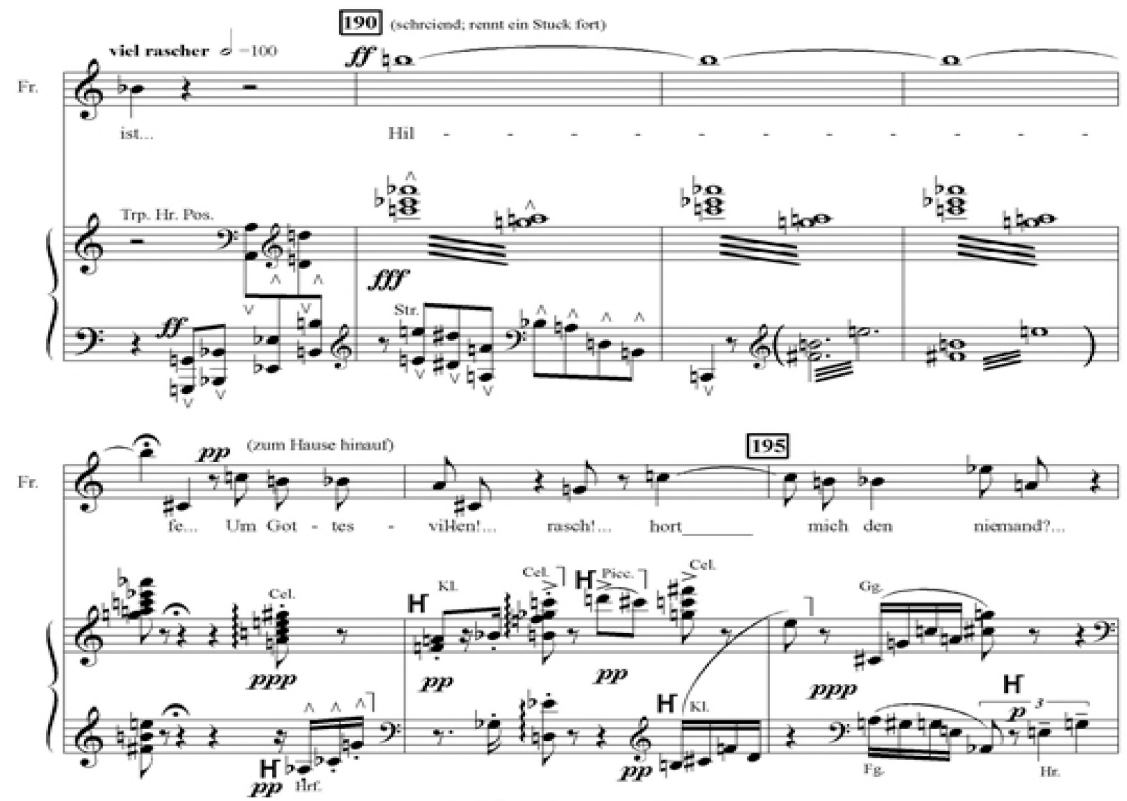

Example 6: Arnold Schönberg, Erwärtung, bars 189-193.

Erwartung's text was written by Marie Pappenheim; her knowledge of psychoanalysis is evident. The poet and distinguished psychiatrist in Vienna, also a professor at Vienna University, taught the theory and method of Freud. In this work, the Woman is possessed by a fixed idea: her continuously alternating thoughts and emotions are depicted while she seeks her lover in the dark forest. It is important to mention that later the composer describes this work as "...this nightmare, this unharmonious torture...these unintelligible ideas...this methodical madness". 11

"Speech at the National Institute of Arts and Letters (1947), quoted in Charles Rosen, Schoenberg, London, The University of Chicago Press, 1975, 10. 


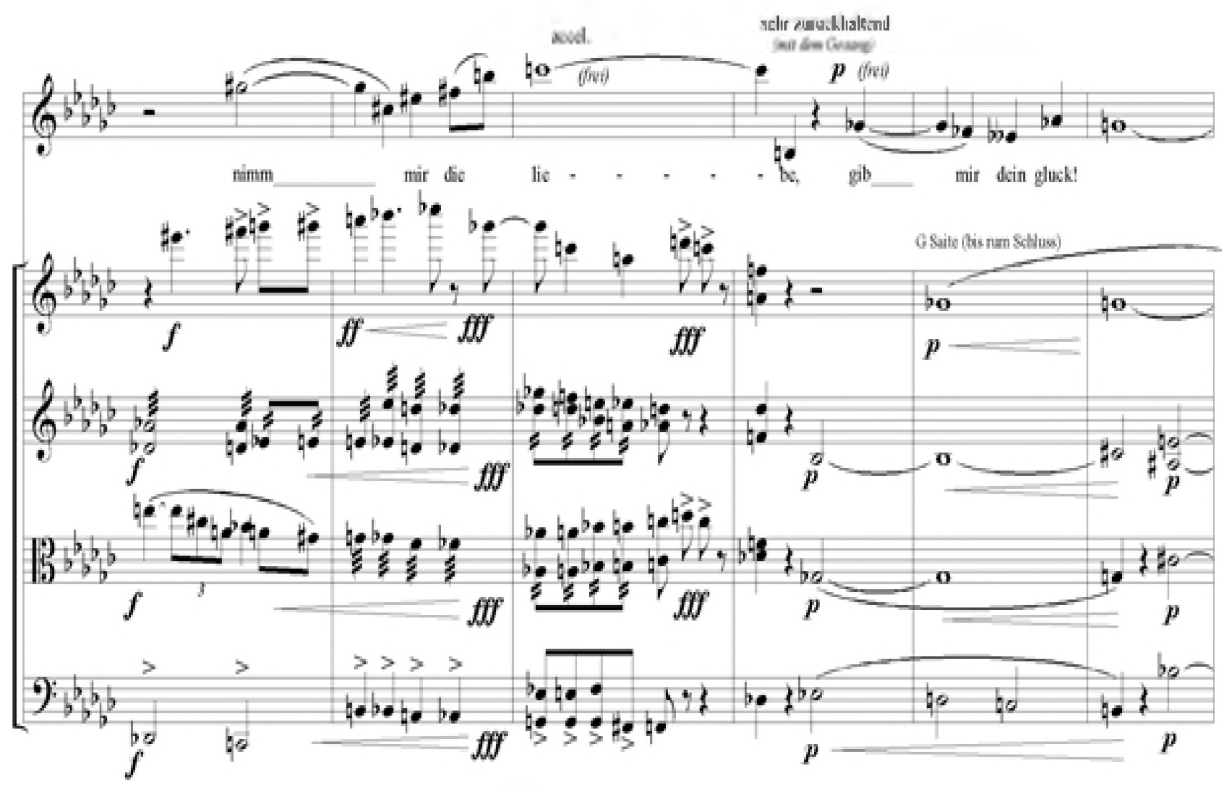

Example 7: Arnold Schönberg, Second String Quartet, bars 63-68.

At the climax of the Second String Quartet, Litanei, (based on poetic visions by Stefan George entitled Der siebente Ring (1907), which refer to the anguish of a wanderer who seeks spiritual consolation), the words of the example are as follows "[...] take from me [earthly] love, grant me happiness" (Nimm mir die Liebe, gib mir dein Glück!).

In Erwartung, the Woman sings the same high notes for her scream of "Hilfe" as the ones by Kundry, whereas the climax with the word "Liebe" of the Second String Quartet has a similar musical 'quotation' but not the same high notes.

It is easy to associate the terrifying outburst of the protagonist's scream, in both cases, with Munch's 'scream'. Moreover, it can be considered as the climax of the whole endeavour by free atonality, a musical evolution which takes place almost fifteen years after the emblematic work of Munch. ${ }^{12}$ This moment in both

12 For example, Elizabeth Prelinger notes:

"Students of music history today find the Scream in their textbooks used as a visual corollary to the dissonance and atonality of the Expressionist music of Arnold Schoenberg and Alban Berg. The Scream was so modern that one must look forward to the twentieth-century composer Arnold Schoenberg, master of dissonance." (Elisabeth Prelinger, "Music to our Ears? Munch's Scream and Romantic Music Theory", in The Arts Entwined: Music and Painting in the Nineteenth Century, ed. Marshal L., Morton and Peter L. Schmunk, New York, Garland, 2000, 209). 
Siopsi, A., Aural and Visual Manifestations of the Scream in Art...

examples, nevertheless, can be considered as the moment of 'hysteria' of the protagonist and, as Slavoj Žižek rightly observes,

[i]f one feature serves as the clear index of modernism - from Strindberg to Kafka, from Munch to Schoenberg's Erwartung - it is the emergence of the figure of the hysterical woman, which stands for radical disharmony in the relationship between the two sexes. ${ }^{13}$

As I attempted to demonstrate, the three above mentioned references by Schoenberg to Kundry's "Lachte" are references of ideas: the words "Lachen" (Pierrot Lunaire), "Hilfe" (Erwartung) and "Liebe" (Second string Quartet) express irony and, being placed at the climax of the musical works, show distrust of the truth similarly to Kundry's feeling in front of the Crucified. Thus, they express the division, or the disruption, from the truth.

Another characteristic example that refers to the 'primal scream' can be found in Alban Berg's opera Wozzeck, a work which is considered to be the most representative example of expressionism. Berg himself added numerous stage instructions throughout the work. One of them which is characteristically expressionistic refers to the scene with the sunset, at the moment when Wozzeck, while gathering sticks with his friend Andres, suddenly experiences sunset as "... fire! It is heightened from the earth to the sky and calms down as a humming like trombones". (Act 1, scene 2, bars 290-295).

The following staging instruction is:

The sun is about to set. Its long sharp rays diffuse their light on the horizon by means of the brightest sunlight, which is abruptly followed (with the effect of the deepest darkness) by the twilight, which the eyes gradually become used to.

Like Munch, who thought of the sunset as a scream that permeates nature, Berg depicts nature as something threatening while Wozzeck responds to it as he envisions. In music, respectively, the stillness of the previous part (in correspondence with Wozzeck's words "there is an odd stillness... it makes you want to hold your breath") is succeeded in a very effective way by an orchestral "explosion'.

\section{Unresolved screams in painting}

Important unresolved screams in painting, successors of Munch's Scream, appear from as early as the expressionistic era.

Thus, I begin with the woodcut by German artist Erich Heckel (1883-1970) in 1917, entitled Mann in der Ebene [Man on a plain, Self-portrait] (Example 8).

13 Slavoj Žižek, Mladen Dolar, Opera's Second Death, New York, Routledge, 2002, 134. 
Heckel is one of the main representatives of the first expressionist group called Die Brïcke [The Bridge] which was formed in Dresden in 1905. I should mention that the members of this group, in general, due to the importance they attached to the depiction of psychic conditions and emotions by means of lines and drawing, created many engravings (mainly woodcuts) because in this way they could achieve great expressionistic power. ${ }^{14}$ The above mentioned woodcut, in which we see the looming forehead of a lonely figure, the raised hands that emphasize the temples, the carved areas of sky which seem to radiate from the figure, and the dark background which seems to collapse around the figure, convey a sense of psychic turmoil. Obviously it refers to the black-and-white woodcut of the Scream (1895) by Munch. This version of the Scream (woodcut) was the one which was more widely known than the other versions of the painting at the beginning of the twentieth century.

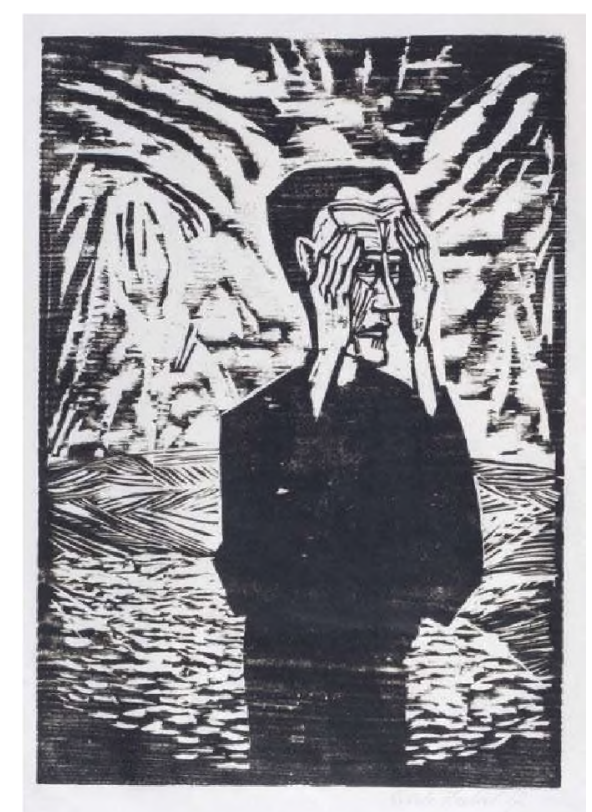

Example 8: Erich Heckel (1883-1970) Mann in der Ebene, Self-portrait

${ }^{14}$ Melita Emmanuil, chapter 2 ("I ikastikes tehnes stin Evropi tin proti pentikontaetia tou $20 \mathrm{ou}$ aiona" [Visual arts in Europe at the first half of the twentieth century], in Ikastikes Tehnes stin Evropi apo ton 180 os ton 200 aiona [Visual Arts in Europe from the $18^{\text {th }}$ to the $20^{\text {th }}$ Century], Vol. B', Patra, EAP (Greek Open University), 2008, 65-117, 73-74. 
The influence of the Scream in modern art is important and is demonstrated in quite a few art works in the course of the twentieth century. I will refer to a few of such important paintings.

Mexican artist David Siqueiros (1896-1974) in 1937 created a painting entitled Echo of a Scream (90X125 cm, Museum of Modern Art, New York), in which he depicts the tragedy of war (Example 9). His works, in general, reflect his strong belief in Marxist ideology. The event which is represented in this painting is the aftermath of a war and the trauma of human loss. More specifically, it represents the Spanish civil war in which the artist was also involved; however, the work's symbolism goes beyond the specific event in order to express a universal protest against the suffering of war.

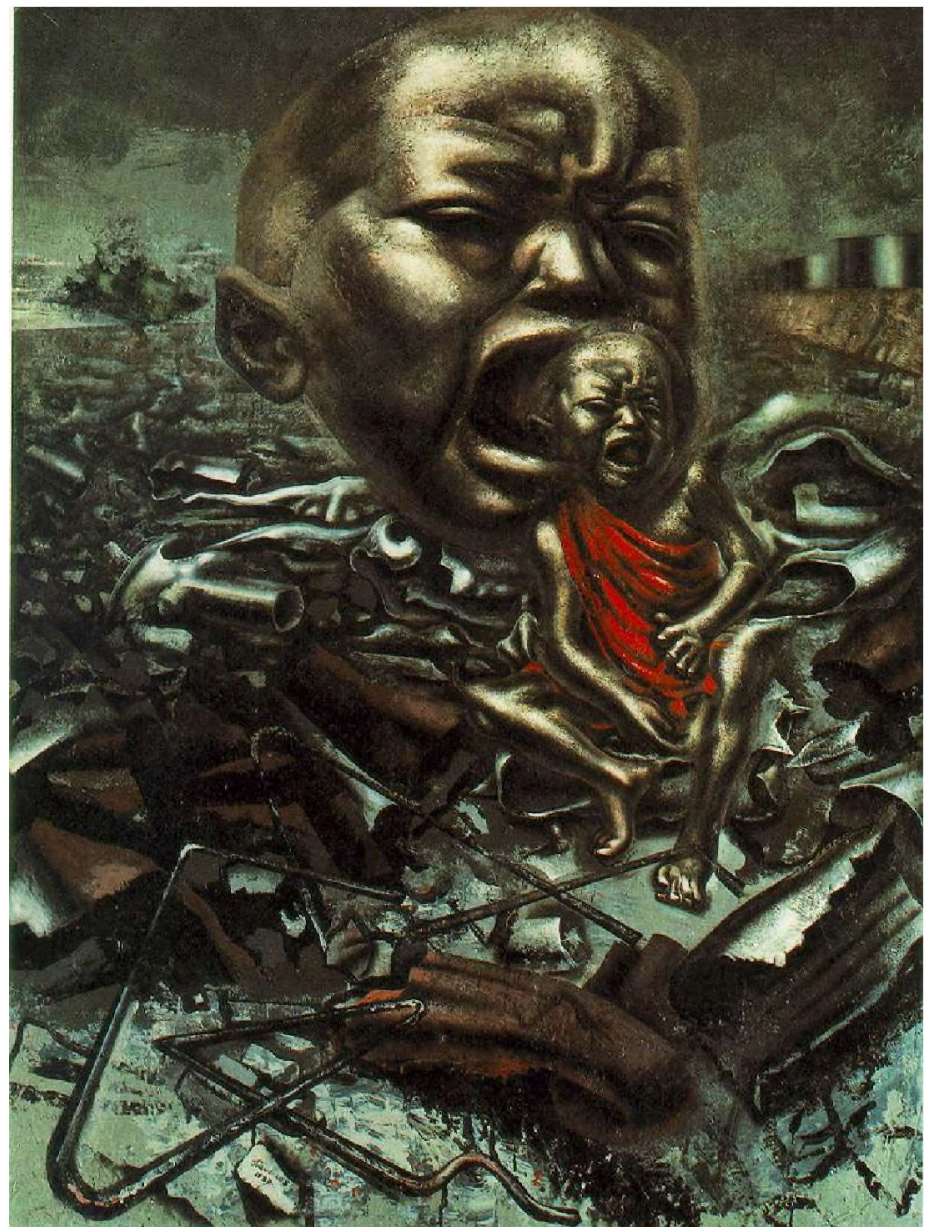

Example 9: David Siqueiros, Echo of a Scream 
The painting is captivating both visually and metaphorically. When we look at the painting the most prominent figure we see are two crying babies. One baby's head is enlarged and the other baby is coming out of his mouth. The baby is sitting on a surface which looks like a war zone. The ground shows the fallout of the war and the destruction that accompanies it. The visible elements are the shells, broken cannons, and shrapnel. ${ }^{15}$ The most prominent emotion to be felt by looking at this work is that of deep sorrow since it seems that there is no hope for a better future.

In the same year, Pablo Picasso (1881-1973) paints his masterpiece entitled Guernica, one of the most important twentieth-century paintings (Example 10). The work was named after a Basque city in northern Spain that was the target of the Nazi bombing ordered by General Franco during the Spanish Civil War. It is a monumental painting $(3,49 \times 7,76 \mathrm{~m}$.) in black, white and grey. It was exhibited in the Spanish Pavilion at the World Fair in Paris, in 1937. Similarly to Siqueiros's painting, Guernica is a war painting, offering a visual account of the devastating and chaotic impact of war on humanity.

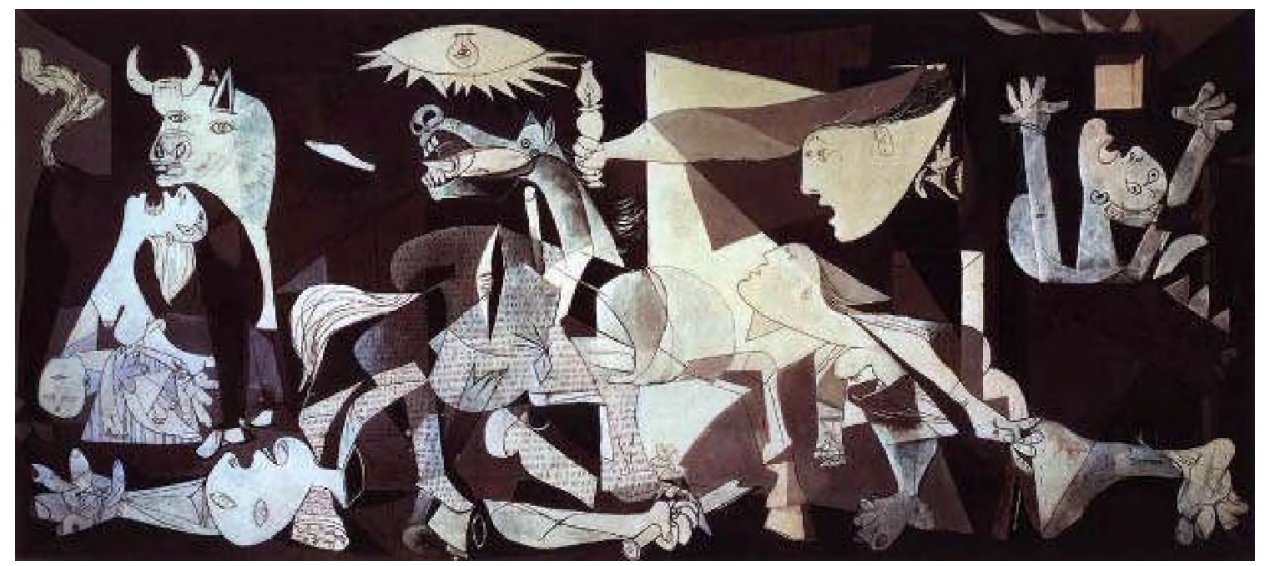

Example 10: Pablo Picasso Guernica

The expressionistic elements that refer to Munch's painting are obvious: first of all, the scene depicted in Guernica is full of moving, screaming and dying adults, children and animals. The screaming is illustrated by a wailing woman with a dead child in her arms (pieta image, the age-old suffering of women in war), a horse (representing innocent people, and, also, symbolizing from very

15 See the description of this painting in "Siqueiro's Echo of a Scream", https://sachinwalia. wordpress.com/2011/08/14/siqueiros-echo-of-a-scream/ (date of access 22/8/2017) 
old times 'Goodness') which is whinnying in agony from a terrible injury in its side, and so forth.

The Scream is also the predecessor of British artist Francis Bacon's (1909-1992) pictures of Screaming/howling Popes, including the Study after Velázquez's Portrait of Pope Innocent X (1953) (Examples 11 and 12).

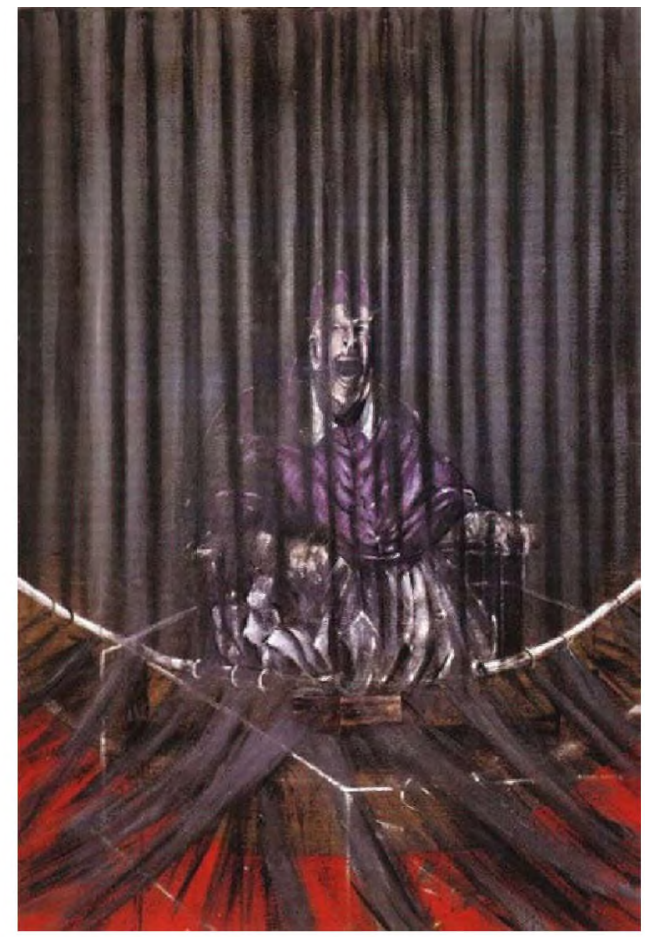

Example 11: Francis Bacon, Screaming / howling Popes

Bacon, who is considered to be one of the most distinguished painters of the second half of the twentieth century in Europe, had as a frequent subject in his paintings the ironic secularization of established types of religious painting. In more general terms, as art historian Alkis Haralabidis observes, "it would be difficult for someone to argue that Bacon's paintings do not make him feel the presence or the threat of violence. Some others, moreover, speak about terror, panic and sadomasochism". ${ }^{16}$

${ }^{16}$ Alkis Haralabidis, I Tehni tou 20ou aiona (tomos III: I metapolemiki periodos) [The Art of the $20^{\text {th }}$ Century (Vol. III: The postwar era)], Thessaloniki, University Studio Press, 1995, 274. 


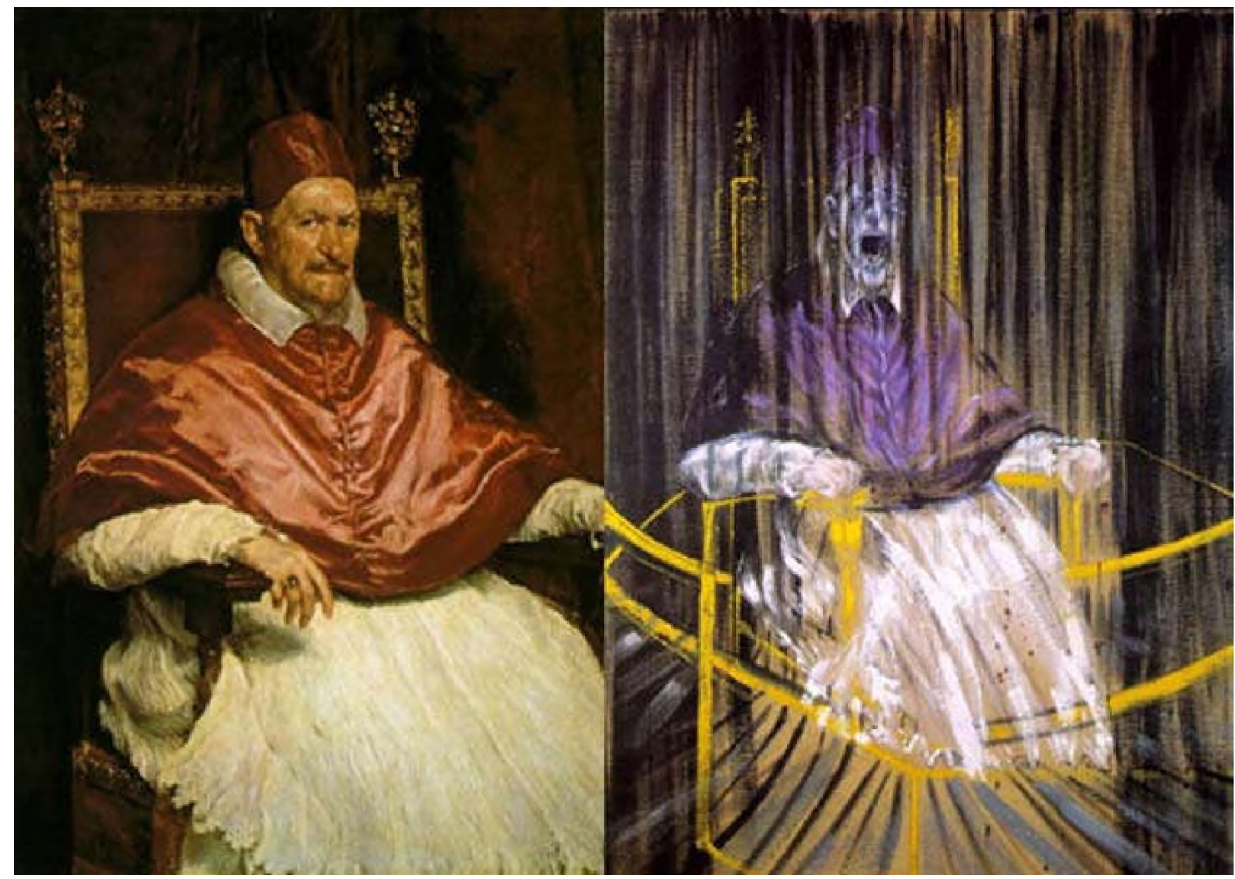

Example 12: Francis Bacon, Study after Velázquez's Portrait of Pope Innocent $X$, Velázquez's work of 1650

The dark religious context of Bacon's works presented here is inspired by photographs of Pope Pius XII. The insertion subverts the encapsulation of power and self-assurance projected by Velázquez (Velázquez painted this work in 1650) and reveals the scream which is hidden within him. ${ }^{17}$ Here, as in many other works by the artist, one of the most legible aesthetic elements is the mouth. The screaming mouth, isolated from other facial features and divorced from any narrative context, suggests existential agony. As Dawn Ades argues, the mouth expresses in a natural way the most condensed anxiety or ecstasy and with this expression man becomes more like an animal. Georges Bataill states that "in moments of extremes, human life 'concentrates' brutally in the mouth. Our anger makes us clench our teeth, terror and horrible torture make our mouth the instrument of agonizing screams." 18

17 Melita Emmanuil, chapter 3 ("I ikastikes tehnes stin Evropi kai stin Ameriki kata ti deuteri pentikontaetia tou 20ou aiona" [Visual arts in Europe and in America in the second half of the twentieth century], op. cit., 119-180, 167.

18 Alkis Haralabidis, op. cit., 275. 
The distorted open mouths of the works we present here refer to Munch's Scream, since in this painting, especially in the woodcut version of 1895 , all lines seem to 'direct' our eyes to the only visual center of this work, the screaming head. The screaming head, in both cases - Munch and Bacon - is distorted and, I dare say, resembles the face of death (grim eyes, dull cheeks). Also, in the work entitled Study after Velázquez's Portrait of Pope Innocent $X$, the way that the artist unites the open mouth with the extinct pince-nez is influenced by the distorted mouth of the injured nanny who screams in the film entitled Battleship Potemkin by Sergei Eisenstein. ${ }^{19}$

One of the most stunning things about The Scream is not its impact upon subsequent art, but the way it transcended art history to become a touchstone of popular culture. I am referring to the silkscreen-prints entitled The Scream (After Munch) by Andy Warhol (1928-1987) which recast Munch's Scream in bright, eye-popping colors.

Warhol was the most famous and most controversial among the pop artists. Based on methods by graphic arts and silkscreen printing, Warhol became the most prominent exponent of the consumer society and the world of advertising. ${ }^{20}$ On this specific occasion, he took advantage of the opportunity to pay ironic homage to such a famous painting, by making only minor distortions mainly of the colours - of the original image by Munch (see Example 13).

More generally, pop culture has 'embraced' Munch's work, by producing works in all kinds of art, for example the mask in the thriller entitled Scream or the 'bad guys' in Doctor Who.

\section{Conclusion}

In conclusion, the diachronicity of the scream, of a primal scream that remains unresolved, 'floating', in order to articulate existential terror, human 'hysteria', the scream of a tormented soul according to psychoanalysis, or of the 'collective shadow' according to Carl Jung, found its ideal form in Edward Munch's painting.

If we accept that many of the most important issues brought forth by the greatest artistic achievements refer to elements of human nature common to all of us and unchanged throughout the passage of time - mortality, hunger, pain, sexual urges, humour, sadness, and so forth - it would not be difficult to include Munch's Scream, as well as its 'echo' in important twentieth-century art works, in this category.

19 Melita Emmanuil, op. cit., 167-8.

${ }^{20}$ Ibid., 146. 

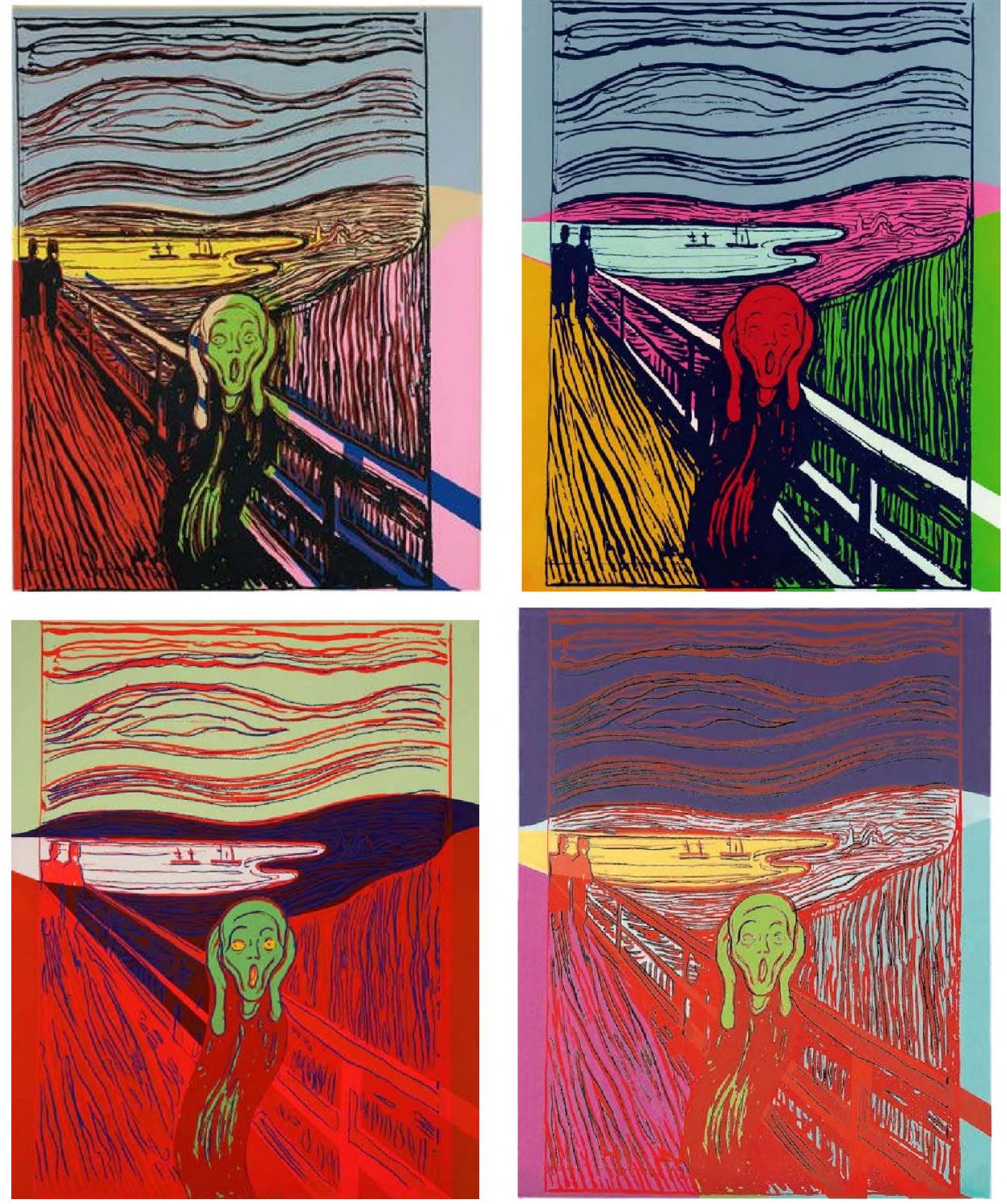

Example 13: Andy Warhol, The Scream (After Munch), 4 versions

Nevertheless, the idea of the 'scream' of a dying God, of an odd figure that presses her ears with her hands, expressing the emotions of fear and anguish, has still a valid meaning in our days. It represents the twentieth and twentieth-first century human being cut loose from all the certainties that had comforted him until the previous century, the modern man with no God, no tradition, no habits 
Siopsi, A., Aural and Visual Manifestations of the Scream in Art...

or customs, in a state of existential crisis, facing a universe he does not understand and can only relate to in a feeling of panic.

A characteristic example of this idea of panic is the one which the composer Jani Christou ${ }^{21}$ embodies in Oresteia, the last and unfortunately unfinished work he composed; here Christou intentionally changes the end of the homonymous ancient tragedy in order to indicate that the world has no hope of a happy end. In his last interview given for this work Christou speaks about "the panic because of the lack of a solution to the problem of human existence". ${ }^{22}$

Thus, the Scream, the painting of the great Norwegian painter Edward Munch, is one of the most resonant images of the twentieth century and beyond, reverberating in all aspects of culture from the most exalted to the most disposable. It is a powerful statement that the heavens no longer resound with the music of the spheres but with a primal scream that echoes from the dawn of time. And it succeeds in depicting in an unsurpassable way the moment when to use the words of the artist himself - "[My friends went on walking, while]... I lagged behind, shivering with fear. Then I heard the enormous infinite scream of nature".

21 Jani Christou (1926-1970) is a very important Greek composer whose work as a whole is characterized by the spirit of spontaneity, apparent simplicity and authenticity. From 1963 to 1969 , Jani Christou wrote music for four ancient tragedies and one ancient comedy (in chronological order, Prometheus Bound (1963), The Persians (1965), Agamemnon (1965), The Frogs (1966), Oedipus Rex (1969)). There is a parallel development of musical language and philosophical thought; catharsis seems to be the ultimate aim of the audience's experience of his work as a ritual.

The complete transformation of time to a continuous, cyclic dimension, without the sense of beginning and end, that is, the fullest adaptation of a play to the mythological dimension of time, takes place in the music that Christou wrote for the Oresteia, a 'contemporary opera', as the composer named this work, which was a free adaptation of Aeschylus homonymous work. The most important change of Aeschylus's text is the end: in Christou's opera there is no salvation at the end which is a commentary of the modern world. Instead, the opposites continue forever, articulating the eternal repetition of cycles without the ability to escape. See, for example, Anastasia Siopsi, "Post-avant garde elements in Jani Christou's music for ancient dramas (1963-1969)", Proceedings of the International Conference Beyond the Centres: Musical Avant-gardes since 1950, Thessaloniki, Greece, 1-3 July 2008, http://bte.web. auth.gr/

22 See a reference to the correlation of Oresteia with "the panic of the lack of a solution to the problem of human existence" by Christou in Anna M. Lucciano, Jani Christou: The Works and Temperament of a Greek Composer, Amsterdam, Harwood Academic Publishers, $2000,120$. 


\section{Works cited}

Adler, Margot: "Scream' Still Echoes After More Than A Century", in http://www.npr. org/2012/05/02/151706441/scream-still-echoes-after-more-than-a-century (21/8/2017).

Emmanuil, Melita: "I ikastikes tehnes stin Evropi tin proti pentikontaetia tou 20ou aiona [Visual arts in Europe at the first half of the twentieth century]", Ikastikes Tehnes stin Evropi apo ton 180 os ton 20 o aiona [Visual Arts in Europe from the $18^{\text {th }}$ to the $20^{\text {th }}$ Century]. vol. B', Patra, EAP, Greek Open University, 2008.

---: "I ikastikes tehnes stin Evropi kai stin Ameriki kata ti deuteri pentikontaetia tou 20ou aiona [Visual arts in Europe and in America at the second half of the twentieth century]", Ikastikes Tehnes stin Evropi apo ton 180 os ton 20 o aiona Tisual Arts in Europe from the $18^{\text {th }}$ to the $20^{\text {th }}$ Century]. vol. B', Patra, EAP, Greek Open University, 2008.

Gombrich, E.H.: To Hroniko tis tehnis [The Art's Chronicle]. Athens: Morfotiko Idrima Ethnikis Trapezis, 2003.

Haralabidis, Alkis: I Tehni tou 20ou aiona (tomos III: I metapolemiki periodos) [The Art of the 20 $0^{\text {th }}$ Century (vol. III: The postwar era)]. Thessaloniki: University Studio Press, 1995.

Hodin, J.P.: Edvard Munch. London: Thames and Hudson, 1972.

Lucciano, Anna M.: Jani Christou: The Works and Tamperament of a Greek Composer. Amsterdam: Harwood Academic Publishers, 2000.

Prelinger, Elisabeth: "Music to our Ears? Munch's Scream and Romantic Music Theory", The Arts Entwined: Music and Painting in the Nineteenth Century, Ed. by Marshal L., Morton and Peter L. Schmunk. New York: Garland, 2000.

Prideaux, Sue, Edvard Munch. Behind the Scream, Yale University Press, 2005.

Rosen, Charles, Schoenberg. London: Fon tana/Collins, 1975.

Siopsi, Anastasia: "Esthitikes prosegiseis ston Pierrot Lunaire (1912), op. 21, tov Arnold Schoenberg [Aesthetic approaches to Pierrot Lunaire (1912), op. 21, by Arnold Schoenberg]", Porphyras (philological journal), vol. KD', n. 110, Jan.-Mar. 2004.

---: "Post-Avant garde elements in JaniChristou's music for ancient dramas (1963-1969)", Proceedings of the International Conference Beyond the Centres: Musical Avant-gardes since 1950. Thessaloniki, Greece, 1-3 July 2008, http://btc.web.auth.gr/.

---: Richard Wagner. Dokimia gia tin aisthitiki tis theorias kai tou ergou tou [Richard Wagner. Essays on the aesthetics of his theory and work]. Athens: Papagrigoriou-Nakas publications (Greek Musicological Publications), 2013.

"Siqueiro's Echo of a Scream", https://sachinwalia.wordpress.com/2011/08/14/ siqueiros-echo-of-a-scream/ (date of access 22/8/2017).

STRINDBERG, A LIFE - SUE PRIDEAUX ON THE PLAYWRIGHT'S RELATIONSHIPS, http://yalebooksblog.co.uk/2013/07/08/strindberg-a-life-author-sue-prideauxon-the-playwrights-relationships/ (14\8\16).

Žižek, Slavoj, Mladen Dolar, Opera's Second Death. New York: Routledge, 2002. 


\section{Summary}

In Munch's painting, entitled "Der Schrei der Natur" (1893), a figure, while walking on a bridge, feels the cry of nature, a sound that is sensed internally rather than heard with the ears.

The composition, the "Scream" exists in four forms that have been painted in 1889-1909. The first painting, done in oil, tempera, and pastel on cardboard (1893, National Gallery of Art, Oslo); two pastel examples (1893, Munch Museum, Oslo and 1895, private collection); and a final tempera painting (1910, National Gallery of Art, Oslo). Munch also created a lithographic version in 1895.

They articulate repeatedly the same idea: that of the profound dissonance with one's sonic environment. Moreover, the "Scream" is thought to be the ultimate embodiment of fear, angst and alienation. It is also thought to symbolize humanity's existential panic expressed by ugly, even hideous, sounds of living beings undergoing both physical and emotional suffering in the modern age.

As a motive, the so-called 'Ur-schrei', is manifested mainly, but not only, in expressionist literature, painting and music, in order to articulate the most intense human emotions. In this article, I present and analyze aural and visual manifestations of the "Scream" in music and painting. 